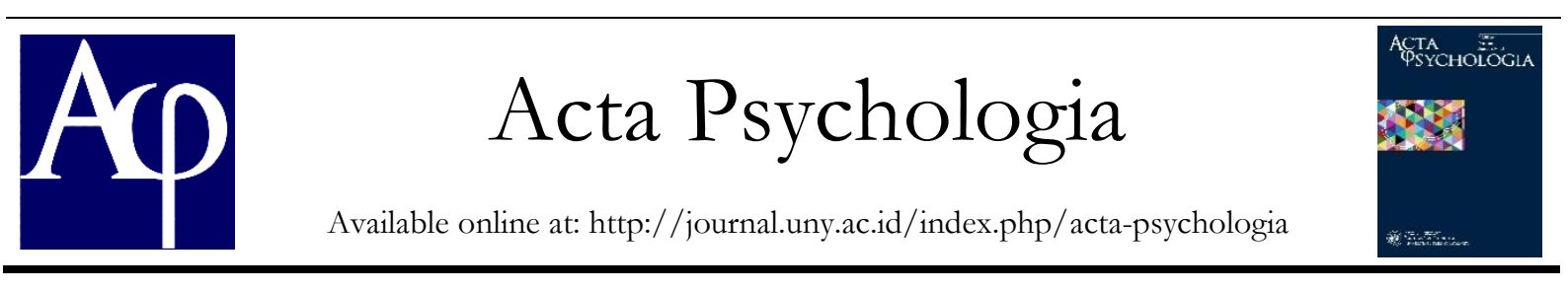

\title{
Penerimaan Diri pada Ibu dengan Anak Tunagrahita
}

\author{
Dian Pertivi Simamora \\ Jurusan Psikologi, Fakultas Ilmu Pendidikan, Universitas Negeri Yogyakarta; \\ Jl. Colombo No. 1 Sleman Yogyakarta, 55281 \\ diansimamor13@gmail.com
}

\begin{abstract}
Abstrak
Setiap ibu menginginkan anaknya lahir dalam keadaan normal dan sehat, harapan muncul sejak anak masih di dalam kandungan, keadaan berbalik saat ibu mendengar diagnosis anaknya yang tunagrahita. Berbagai masalah psikologis dialami ibu sebelum akhirnya mencapai tahap penerimaan diri. Proses untuk dapat menerima keadaan diri sebagai ibu dari anak tunagrahita merupakan proses yang sulit. Setiap ibu memiliki proses dan cara masing-masing untuk mencapai tahap itu. Penelitian ini bertujuan untuk mendeskripsikan gambaran penerimaan diri pada ibu dengan anaknya tunagrahita. Metode yang digunakan dalam penelitian ini adalah pendekatan kualitatif dengan jenis studi kasus. Hasil dari penelitian ini diambil dari tiga orang subjek secara purposive dengan kriteria ibu yang memiliki anak tunagrahita di SDN Gejayan Yogyakarta. Metode pengumpulan data menggunakan wawancara. Teknik analisis data menggunakan reduksi data, display data, dan kesimpulan. Uji keabsahan data menggunakan teknik triangulasi sumber dan member checking. Hasil penelitian ini menunjukkan bahwa semua subjek memiliki penerimaan diri yang baik. Ketiga subjek menunjukkan penerimaan diri terhadap kondisi yang dialami anak yaitu tunagrahita. Setiap subjek mengalami fase masing-masing untuk menuju tahap penerimaan. Fase tersebut adalah denial, anger, bargaining, depression, dan acceptance. Setiap subjek mengalami fase yang berbeda antara satu dengan lainnya. Fase penerimaan ini tidak selalu terjadi secara berurutan.
\end{abstract}

Kata Kunci: penerimaan diri, tunagrabita, ibu, kualitatif

\begin{abstract}
Every mother wants her child born in the normal and healthy condition, hopes to emerge since the child was still in the womb. The state turned around when the mother heard her child diagnosis in mentally retarded child. A variety of psychological problems has been experienced by mother before reaching the stage of self- acceptance. Process to be able to receive the state itself as the mother of the child with mental retardation is a difficult process. Every mother has the process and how to achive each of these stages. The research's subjects are three mother who raises kids with mentally retarded. This research aims to obtain an overview of self-acceptance of mothers who have mentally retarded children. This research using a qualitative method with a case study approach. Data collected using the interview method and analyzed by data reduction, data display, and conclusions verification. The validity tests of the data use data triangulation techniques namely source triangulation and member checking. The result of this study indicate that all subjects have good self-acceptance. The three subjects showed self-acceptance of the condition of mentally retarded children. Each subject experiences each phase to reach the acceptance stage. The phase is denial, anger, bargaining, depression and acceptance. Evey subject experiences a different phase from one to another. This acceptance phase does not always occur sequentially.
\end{abstract}

Keywords: self-acceptance, child with special need, mother, qualitative

\section{Pendahuluan}

Setiap anak terlahir dengan kondisi yang berbeda. Ada yang lahir dengan kondisi normal dan ada yang lahir dengan kelainan, baik secara fisik maupun mental. Anak dengan kondisi berbeda dengan anak normal disebut Anak Berkebutuhan Khusus (ABK). Anak berkebutuhan khusus adalah anak dengan karakteristik khusus yang berbeda dengan anak umumnya (Faradina, 2016). 
Tidak dapat dipungkiri bahwa semua orang tua mengharapkan anaknya lahir sempurna, tumbuh sehat, pandai serta cerdas. Bila ditanya apakah Anda siap memiliki anak berkebutuhan khusus? Tentu saja sebagian besar orang tua serentak akan menjawab "tidak". Bahkan mungkin tidak terlintas dipikiran orang tua akan mendapatkan anak berkebutuhan khusus dalam kondisi apapun (Mulyadi, 2014). Penerimaan diri orang tua terhadap anak yang memiliki kebutuhan khusus sangat mempengaruhi proses perkembangan anak. Menurut Chaplin (2012) penerimaan diri ditandai dengan sikap positif, adanya pengakuan terhadap tingkah lakunya. Penelitian yang dilakukan oleh Faradina (2016) mengatakan bahwa penerimaan diri orang tua tidak hanya ditandai dengan menerima kondisi anaknya tetapi juga berusaha mengembangkan diri melalui tahap- tahap penerimaan diri, mampu menerima dirinya ketika menghadapi kondisi yang membuat dirinya tidak nyaman serta memiliki pribadi yang matang dan dapat berfungsi dengan baik.

Pentingnya penerimaan diri ibu sangat dibutuhkan dalam persiapan proses pengasuhan anak berkebutuhan khusus, khusunya anak tunagrahita. Ketika ibu dapat menerima keadaan dirinya dengan baik, ibu juga memiliki kemampuan menerima kondisi keadaan anak yang menyandang tunagrahita dan ibu akan mencari tahu mengenai kondisi anaknya dan mempersiapkan secara tepat model pengasuhan yang akan diberikan kepada anaknya yang tunagrahita, sehingga dapat memaksimalkan perkembangan dan pertumbuhan anak (Mahabatti, 2009).

Memiliki anak dengan kondisi kebutuhan khusus dapat mempengaruhi ayah, ibu dan keluarga dalam berbagai aspek kehidupan. Salah satu jenis kebutuhan khusus tersebut adalah anak tunagrahita. Tunagrahita merupakan kata lain dari retardasi mental yang berarti keterbelakangan secara mental.
Mangunsong (2009) menjelaskan bahwa keterbelakagan mental menunjukan adanya keterbatasan yang signifikan dalam berfungsi, baik secara intelektual maupun perilaku adaptif yang terwujud melalui kemampuan adaptif konseptual, sosial dan praktikal.

Di dunia terdapat banyak kasus anak dengan masalah tunagrahita, lebih dari 120 juta orang di dunia menyandang tunagrahita (Retnaningsih, 2013). Menurut World Health Organization (WHO) pada tahun 2011 di Indonesia jumlah anak dengan tunagrahita sebanyak 6.6 juta jiwa (Dinas Kesehatan, 2010). Jumlah anak tunagrahita di DIY tahun 2010, total jumlah anak tunagrahita di Yogyakarta sebanyak 9301 orang yang merupakan jumlah terbesar kedua dibandingkan dengan jumlah kecacatan lainnya dari jumlah penduduk. Kasus tunagrahita di masing-masing wilayah provinsi DIY, sebagai berikut: Kota Yogyakarta 684 orang (7.35\%), Kabupaten Bantul 1968 orang (21.15\%), Kabupaten Kulonprogo 1632 orang (17.54\%), Kabupaten Gunung Kidul 2482 orang (26.68) dan Kabupaten Sleman 2535 (27.25\%) (Dinas Kesehatan, 2010).

Banyak ibu yang awalnya sulit menerima kenyataan bahwa anak yang selama ini dikandung dan lahirkan adalah anak yang menyandang tunagrahita, kenyataan tersebut bertolak belakang dengan harapan sebelum anak lahir (Mangunsong, 2009). Adanya harapan yang tak terpenuhi menyebabkan penerimaan diri pada ibu tersebut rendah. Ada beberapa gejolak emosional yang ditunjukan oleh ibu seperti menangis, kecewa, kaget dan perasaan menyangkal sebelum kemudian menerima keadaan (Mangunsong, 2009).

Kubler Ross (2005) mendefinisikan sikap penerimaan terjadi bila seseorang mampu menghadapi kenyataan daripada menyerah pada tidak adanya harapan. Sebelum mencapai pada tahap penerimaan individu akan melalui beberapa fase yakni, 
tahap denial, anger, bargaining, depression, dan acceptance. Tahapan penerimaan orang tua dalam menerima anak berkebutuhan khusus dimulai dari tahap pertama yaitu denial. Tahapan ini dimulai dari rasa tidak percaya saat menerima diagnosis dari seorang ahli, perasaan orang tua selanjutnya akan diliputi rasa kebingungan dan terselip rasa malu pada orang tua tentang keadaan anaknya untuk mengakui bahwa hal tersebut dapat terjadi di keluarga mereka. Keadaan ini menjadi bertambah buruk, jika keluarga tersebut mengalami tekanan sosial dari lingkungan yang kurang memahami tentang keadaan anak berkebutuhan khusus. Tahap kedua angry, kemarahan ini dilampiaskan orang tua pada hal-hal yang tidak jelas. Kemarahan bisa dilampiaskan kepada dokter yang mendiagnosis, kemarahan kepada diri sendiri atau kepada orang lain, bentuk lain kemarahan antara lain menolak untuk mengasuh anak berkebutuhan khusus. Tahap ketiga depression dalam tahap ini terkadang muncul dalam bentuk rasa putus asa, tertekan dan kehilangan harapan. Tahap keempat bargainig orang tua berusaha untuk menghibur diri dengan pernyataan segala sesuatu yang dikaruniakan Allah harus disyukuri apapun bentuknya. Tahap kelima acceptance. Pada tahapan ini, orang tua sudah berusaha menerima kenyataan dengan kehadiran anak berkebutuhan khusus dalam kelurganya baik secara emosi maupun intelektual.

Reaksi orang tua yang pertama kali muncul pada saat mengetahui bahwa anaknya mengalami kelainan adalah perasaan shock, mengalami goncangan batin, terkejut, dan tidak mempercayai kenyataan yang menimpa anaknya (Mangungsong, 2011). Ibu harus mengorbankan banyak waktu khusus untuk merawat anak tunagrahita. Ibu membutuhkan waktu, tenaga, dan pikiran yang lebih banyak untuk merawat anak tunagrahita karena fungsi kecerdasan dan kemampuan perilaku adaptif anak tunagrahita terbatas. Ibu yang memiliki anak tunagrahita menunjukkan perasaan sedih, depresi, marah dan kurang menerima keadaan anaknya. Ibu merasa khawatir dengan masa depan anaknya dan stigma masyarakat yang melekat pada diri anak.

Berbagai masalah yang dihadapi ibu yang memiliki anak tunagrahita dapat menurunkan penerimaan diri dalam hidupnya. Penelitian yang dilakukan oleh Miyahara (2008) didapati bahwa sebagian keluarga dengan anak tunagrahita terlihat memiliki kehidupan yang lebih baik dibanding keluarga lain sedangkan di sisi lain beberapa orang tua terutama ibu merasa terpuruk, dan mengakibatkan ibu tidak mampu merawat anaknya dengan baik. Dalam referensi tersebut didapatkan temuan bahwa ibu yang sanggup bangkit untuk memberikan pengasuhan terbaik bagi anak mereka adalah ibu yang mampu mengatasi stres psikologis mereka.

\section{Metode Penelitian}

\section{Jenis penelitian}

Penelitian ini menggunakan pendekatan kualitatif dengan jenis studi kasus. Penelitian kualitatif adalah penelitian yang bermaksud untuk memahami fenomena tentang apa yang untuk memberikan perhatian ekstra dan perhatian dialami oleh subjek penelitian secara holistik dengan cara deskripsi dalam bentuk kata-kata dan bahasa pada suatu konteks khusus yang alamiah (Moleong, 2005). Penelitian kualitatif, yang merupakan metode untuk mengeksplorasi dan memahami makna yang oleh sejumlah individu atau sekelompok orang dianggap berasal dari masalah sosial atau kemanusiaan (Creswell, 2013).

Jenis penelitian yang digunakan dalam penelitian ini dengan jenis studi kasus. Penelitian ini berpusat secara intensif pada satu objek tertentu dan mempelajarinya sebagai suatu kasus. Data studi kasus dapat diperoleh dari semua pihak yang bersangkutan dengan objek yang 
akan diteliti, dengan kata lain dalam studi kasus ini dikumpulak dari berbagai sumber (Creswell, 2015). Kasus yang diteliti dalam penelitian ini adalah gambaran penerimaan diri pada ibu yang memiliki anak tunagrahita.

\section{Waktu dan tempat penelitian}

Penelitian ini dilaksanakan di SD Negeri Gejayan Yogyakarta. Peneliti memilih sekolah ini karena sekolah tersebut merupakan sekolah Inklusif dan belum adanya penelitian mengenai penerimaan diri pada ibu yang memiliki anak tunagrahita di SD tersebut. Penelitian dilakukan pada bulan Maret - April.

\section{Subjek penelitian}

Penentuan subjek pada penelitian ini menggunakan purposive (kriteria tertentu), yaitu ibu yang memiliki anak tunagrahita di SD Negeri Gejayan Yogyakarta. Jumlah subjek sebanyak 3 orang.

\section{Teknik pengumpulan data dan instrumen}

Pengumpulan data pada penelitian ini menggunakan wawancara sebagai metode pengumpul data yang utama. Wawancara adalah proses proses interaksi yang dilakukan oleh dua orang atau lebih. Interaksi ini terjadi atas dasar ketersediaan dan dalam seting alamiah, dimana arah pembicaraan mengacu pada tujuan yang telah ditetapkan dengan mengedepankan kepercayaan sebagai landasan utama dalam proses memahami (Herdiansyah, 2013).

Instrumen pengumpulan data yang digunakan yaitu berupa pedoman wawancara. Pedoman wawancara dibuat untuk menjadi patokan dalam membuat pertanyaan wawancara yang disesuaikan dengan tema- tema yang telah dibuat. Adapun tema-tema yang telah dibuat oleh peneliti, yaitu mencakup proses tahapan penerimaan diri ibu yang memiliki anak tunagrahita. Pedoman wawancara disusun berdasarkan teori- teori yang telah diketahui oleh peneliti sebelumnya. Pedoman ini dibuat untuk mendapatkan data yang terperinci, menyeluruh dan sesuai dengan tujuan awal penelitian.

\section{Teknik Analisis data}

Teknik analisis data yang digunakan dalam penelitian ini menggunakan Model Interaktif dari Miles dan Huberman (dalam Herdiansyah, 2015) yang mengemukakan bahwa aktivitas dalam analisis data kualitatif dilakukan secara interaktif dan berlangsung secara terus menerus sampai tuntas, yakni data yang didapat telah cukup dan tidak ada lagi informasi yang dapat digali. Adapun tahapan dalam menganalisa data Model Interaktif dari Miles dan Huberman adalah sebagai berikut:

\section{Pengumpulan data}

Langkah pertama peneliti adalah mengumpulkan data sebanyak-banyaknya sesuai kebutuhan. Data yang dikumpulkan adalah data primer maupun data sekunder. Apabila kedua jenis data ini dapat diperoleh, maka akan mempermudah peneliti untuk menyelesaikan penelitian ini.

\section{Reduksi Data}

Reduksi data adalah proses menggabungkan segala data yang diperoleh menjadi bentuk tulisan yang akan dianalisis. Menyeleksi data yang telah terkumpul untuk dapat menemukan data yang penting, berguna, dan sesuai dengan tujuan penelitian. Dalam reduksi data, diperluan kejelian, kefokusan peneliti, dan ketegasan peneliti guna memilih dan memilih data yang diperlukan.

\section{Penyajian Data}

Peneliti dapat menggabungkan data yang telah direduksi untuk menggambarkan data dalam bentuk apapun seperti tulisan, bagan, diagram, dan sebagainya. Penyajian data bertujuan agar data yang diolah dapat dengan mudah dimengerti oleh para pembaca. Proses penyajian data dilakukan dengan mengolah data yang telah direduksi menjadi sub-kategori tema dan proses 
pengkodean (coding). Penyajian data pada penelitian ini akan disajikan dalam bentuk tabel.

\section{Penarikan kesimpulan}

Setelah berhasil menyajikan data, peneliti dituntut untuk mampu menarik kesimpulan sesuai dengan tahapan yang telah dilakukan maupun informasi yang didapatkan. Hasil dari penarikan kesimpulan ini adalah menjawab pertanyaan penelitian berdasarkan hasil temuan peneliti secara spesifik.

\section{Uji keabsahan data}

Uji keabsahan data menjadi hal yang penting bagi penelitian dengan jenis deskriptif kualitatif. Hal ini dikarenakan sumber-sumber data yang digunakan tidak bisa dipastikan kebenarannya secara langsung, maka peneliti diharuskan mampu menguji kevalidannya. Peneliti memilih teknik tringulasi data guna mengetahui kevalidan dari data yang diperoleh. Triangulasi adalah teknik membandingkan data yang diperoleh dengan beberapa sumber lainnya. Peneliti akan melakukan tringulasi sumber. Tringulasi sumber merupakan kegiatan membandingkan informasi yang diperoleh dari hasil wawancara dengan seluruh subjek penelitian. Cara ini menggunakan perspektif orang lain atau informan yang datanya digunakan untuk memperjelas apakah yang dikatan subjek adalah benar atau bohong Marvasti (2004).

\section{Hasil Penelitian dan Pembahasan}

Berdasarkan hasil penelitan yang dilakukan pada tiga subjek yang memiliki anak tunagrahita, diketahui bahwa ketiga subjek sampai pada fase penerimaan. Ketiga subjek mengalami beberapa tahapan sebelum sampai pada fase penerimaan. Masing-masing subjek melewati tahapan yang berbeda dan tidak sesuai urutan. Subjek S1 melewati fase denial, anger, depression, bergaining, kemudian acceptance. Pada subjek S2 hanya melewati tiga fase saja, yaitu fase denial, bargaining dan fase acceptance. Sedangkan pada subjek S3 melewati kelima fase. Hal ini sesuai dengan pernyataan (Kubler-Ross, 2005) dimana fase-fase yang dialami tidak selalu harus diselesaikan sesuai urutan.

Ketiga subjek melewat fase yang sama pada tahapan denial, bargaining, dan acceptance. Fase denial yang muncul pada penelitian ini adalah perasaan shock dan tidak percaya dengan kenyataan yang ada. Dimana reaksi yang pertama kali muncul dari ketiga subjek saat pertama kali muncul adalah perasaan shock dan tidak mempercayai kenyataan yang ada. Hal ini sesuai dengan pernyataan (Mangungsong, 2011) Reaksi orang tua yang pertama kali muncul pada saat mengetahui bahwa anaknya mengalami kelainan adalah perasaan shock, mengalami goncangan batin, terkejut, dan tidak mempercayai kenyataan yang menimpa anaknya.

Pada fase bargaining ketiga subjek berusaha untuk menerima keadaan anak dengan membuat harapan-harapan yang ingin diwujudkan untuk masa depan anak kedepannya. Ketiga subjek juga dapat bersyukur dengan keadaan anak yang tunagrahita dan merasa anak adalah pemberian Allah dan harus dapat diterima bagaimana pun keadaan anak. Ketiga subjek ingin mewujudkan harapan mereka yang sesuai dengan kemampuan dan keinginan anak, dimana ketiga subjek tidak memaksakan kehendak mereka kepada anaknya. Hal ini sesuai dengan hasil penelitian Devina dan Penny (2016) dimana saat berada dalam fase bargaining, dipengaruhi oleh faktor pemahaman diri mengetahui kemampuan dan kelemahan yang dimiliki. Keadaan ini mendukung subjek untuk membuat harapan yang 
realistis setelah mengetahui diagnosa anaknya.

Pada subjek S1 dan S3 tidak melewati semua tahapan untuk sampai pada fase penerimaan. Hal ini sesuai dengan pernyataan (Kubler-Ross, 2005) dimana fase- fase yang dialami tidak selalu harus diselesaikan selalu urut, atau dilalui semuanya oleh seorang individu, tapi paling tidak ada 2 fase yang pasti akan dilalui. Berbeda dengan subjek S2 yang melewati semua tahapan untuk sampai pada fase penerimaan. Subjek S2 lebih lama menerima keadaan anaknya dikarenakan subjek S2 tahu bahwa anaknya tunagrahita di saat anak memasuki bangku sekolah kelas 4SD. Subjek S2 awalnya sangat menolak dan tidak mau percaya bahwa anaknya adalah anak tunagrahita, hal ini ditunjukkan subjek dengan subjek melakukan tes IQ sampai 4 kali terhadap anaknya. Subjek S2 merasa depresi dan sering menangis dengan keadaan anaknya dan hal ini berlangsung selama 2 tahun. Subjek S2 mulai memasuki fase penerimaan setelah anak masuk ke SDN Gejayan di Yogyakarta dan mendapatkan dukungan dari orang tua yang anaknya juga ABK. Hal ini sesuai dengan pernyataan (Kubler-Ross, 2005) dimana proses duka adalah hal yang sangat personal dan sebaiknya tidak dipercepat (atau diperpanjang). Kebanyakan orang tidak siap menghadapi duka, karena seringkali, tragedi terjadi begitu cepat, dan tanpa peringatan. Subjek harus bekerja keras melalui proses tersebut hingga akhirnya sampai pada fase penerimaan. Subjek S2 tidak siap untuk menerima kenyataan bahwa anaknya adalah anak tunagrahita dan harus berusaha untuk dapat menerima kenyataan bahwa anaknya adalah anak tunagrahita.

Ketiga subjek memiliki penerimaan diri yang baik terhadap anaknya, dimana ketiga subjek dapat menjalani kesehariaan dengan bahagia dan menerima semua kekurangan dan kelebihan pada anak. Ketiga subjek tidak mengalami kesulitan dalam keseharian dann tetap semangat untuk mewujudkan harapan- harapan subjek kepada anaknya.

Meskipun memiliki penerimaan diri yang baik, bukan berarti subjek tidak lagi merasakan fase di atas. Pada subjek S1 dan S3 beberapa kejadian atau peristiwa, subjek bisa saja merasakan fase marah. Hal ini terjadi karena beberapa faktor, pada subjek S1 fase anger muncul pada saat subjek sedang lelah dan dan kondisi anak sulit untuk diatur. Dimana anak subjek sangat suka berlari dan berjalan-jalan. Subjek S1 merasa marah pada keadaan dan berusaha untuk tidak memarahi anak. Pasa subjek S3 fase anger ini bisa muncul kembali saat subjek sedang mengajarkan anaknya, dimana anak subjek sulit mengerti meskipun subjek sudah menjelaskan berkali-kali yang membuat subjek terkadang kembali marah kepada keadaan dan sampai memarahi anaknya. Setelah itu subjek merasa menyesal karena sudah marah kepada anaknya. Muncul kembali rasa khawatir dengan masa depan anaknya. Hal ini sesuai dengan hasil penelitian Devina dan Penny (2016) dimana subjek sudah mencapai fase acceptance, namun melewati berbagai proses yang tidak selalu bergerak maju.

Keadaan anak tunagrahita menimbulkan reaksi emosi negatif pada ibu, dimana ketiga subjek awalnya menolak kenyataan bahawa anak mereka tunagrahita. Upaya yang dilakukan ketiga subjek untuk mengatasi emosi negitif tersebut adalah berdoa kepada Tuhan. Keyakinan subjek pada Tuhan mempengaruhi penerimaan pada keadaan diri dan anaknya. Keyakinan subjek pada Tuhan membuat subjek lebih bersyukur dengan hadirnya anak. Pengaruh religiusitas pada melewatkan fase depression yang tidak dilewati oleh subjek penerimaan 
diri juga ditemukan dalam penelitan Mukti \& Dewi (2013) bahwa religiusitas memiliki hubungan dengan penerimaan diri.

\section{Simpulan dan Saran}

\section{Simpulan}

Hasil penelitian ini menunjukkan bahwa ketiga subjek sampai pada fase penerimaan diri. Ketiga subjek menunjukkan penerimaan diri terhadap kondisi yang dialami anak yaitu tunagrahita. Setiap subjek mengalami fase masing-masing untuk menuju tahap penerimaan. Fase tersebut adalah denial, anger, bargaining, depression dan acceptance. Setiap subjek mengalami fase yang berbeda antara satu dengan lainnya. Ada subjek yang melewati seluruh fase dan ada subjek yang hanya melewati 3 fase. Berdasarkan hasil penelitian fase penerimaan ini tidak selalu terjadi secara berurutan. Meskipun ketiga subjek sudah mencapai fase penerimaan, terkadang masih bisa kembali ke fase sebelumnya. Hal ini dapat dipengaruhi oleh suatu peristiwa dimana subjek memikirkan masa depan anaknya.

\section{Saran}

Berdasarkan kesimpulan yang telah disebutkan sebelumnya, peneliti akan memberikan saran kepada beberapa pihak di antaranya adalah:

1. Bagi ibu dengan anak tunagrahita

Bagi Ibu yang belum dapat menerima kondisi anak, agar dapat mengubah pandangan dan penilaian negatif terhadap anak tunagrahita jika anak tunagrahita tidak memiliki kemampuan apapun. Ibu perlu menggali lebih banyak lagi pemahaman tentang anak tunagrahita dengan cara mencari informasi tentang anak tunagrahita melalui buku, majalah ataupun media elektronik.
2. Bagi keluarga

Keluarga diharapkan dapat lebih memberikan dukungan dan perhatian pada ibu yang memiliki anak tunagrahita sehingga ibu dapat mencapai fase penerimaan diri dan memberikan pengasuhan yang baik pada anak

3. Peneliti selanjutnya

Diharapkan pada penelitian berikutnya agar dapat lebih mengembangakan penelitian tentang penerimaan diri pada ibu yang memiliki anak tunagrahita, memperbanyak subjek penelitian agar mendapatkan data yang lebih banyak dengan menggunakan metode wawancara.

4. Pihak sekolah

Guru wali kelas diharapkan memberikan informasi mengenai keadaan anak tunagrahita kepada ibu yang memiliki anak tunagrahita. Dalam hal ini ibu perlu mendapatkan gambaran informasi penyebab tunagrahita, dan penanganan yang dapat dilakukan ibuuntuk mengasuh anaknya. Adapun bagi Kepala Sekolah diharapkan dapat memberikan penyuluhan kepada ibu-ibu yang memiliki anak tunagrahita yang berisi informasi bagaimana pola asuh yang tepat untuk anak tunagrahita dan mengadakan sharing kepada para ibu untuk saling bercerita danmenguatkan.

\section{Daftar Pustaka}

Chaplin, J. P. (2012). Kamus lengkap psikologi. Jakarta: Rajawali Press.

Creswell, J. (2013). Research design pendekatan kualitatif, kuantitatif, dan mixed. Yogyakarta: Pustaka Pelajar.

Creswell, J. (2015). Penelitian kualitatif dan desain riset memilib di antara lima 
pendekatan. Yogyakarta: Pustaka Pelajar.

Devina, G., \& Penny, H. (2016). Gambaran proses penerimaan diri ibu yang memiliki anak tunagrahita. IJDS, 3(1), 44-52.

Faradina, N. (2016). Penerimaan diri pada orang tua yang memiliki anak berkebutuhan khusus. E-Journal Psikologi, 4(4), 386.

Herdiansyah, H. (2015). Metodologi penelitian kualitatif untuk ilmu Psikologi. Jakarta: Rajawali Press.

Kübler-Ross, E. (2009). On death and dying: what the dying have to teach doctors, nurses, clergy and their own families. London: Routledge.

Mahabbati, A. (2009). Penerimaan dan kesiapan pola asuh ibu terhadap anak berkebutuhan khusus. Jurnal Pendidikan Khusus, 5(2), 75-82.

Mangunsong, F. (2009). Psikologi dan pendidikan anak berkebutuhan khusus. Jilid 1. Depok: Lembaga Pengembangan Sarana Pengukuran dan Pendidikan Psikologi.

Mangunsong, F. (2011). Psikologi dan pendidikan anak berkebutuban khusus jilid kedua. Depok: LPSP3 UI.

Miyahara, M. (2008). Social support for developmental disabilities: Theoretical framework, practice, and research agenda. New Zealand Journal of Disabilities Studies, 13, 1423.

Moleong, L. J. (2005). Metodologi penelitian kualitatif. Bandung: Remaja Rosdakarya.

Mukti, D. I., \& Dewi, D. S. (2013). Hubungan antara religiusitas dengan penerimaan diri pada pasien stroke iskemik di RSUD Banjarnegara. Psycho Idea, 11(2), 3540.
Mulyadi, K., \& Sutadi, R. (2014). Autism is Curable Benar, Autisme dapat Disembubkan). Jakarta: PT Alex Media Komputindo.

Ross, K. (2005). Death and dying. (ed 8). Swiss: Medical school University Zurich 